\title{
Effect of Three Levels of Fertilization on the Productivity of Stargrass Pastures Growing on a Steep Ultisol in the Humid Mountain Region of Puerto Rico ${ }^{1,2}$
}

\author{
Rubén Caro-Costas, Fernando Abruña and José Vicente Chandler ${ }^{3}$
}

\begin{abstract}
Stargrass pastures in the humid mountain region of Puerto Rico responded in terms of cattle gain in weight and carrying capacity to fertilization up to $4,480 \mathrm{~kg} / \mathrm{ha}(4,000 \mathrm{lb} /$ acre $)$ yearly of $15-5-10$. With $3,136 \mathrm{~kg} / \mathrm{ha}$ of fertilizer the pastures produced $1,337 \mathrm{~kg} / \mathrm{ha}(1,194 \mathrm{lb} / \mathrm{acre})$ weight gain yearly and had a carrying capacity of $6.8273-\mathrm{kg}$ steers/ha (2.72 600-lb steers/acre). Average daily gain of .61 kg/head (1.35 lb/head) was not affected by variation in rate of fertilization.

Neither apparent digestibility of the forage, calculated from total digestible nutrients utilized by the cattle and the dry forage consumed by the grazing cattle, nor in vitro digestibility of the forage samples were affected by changes in fertilization rate.

Crude protein content of the forage consumed by the grazing cattle was very high at all fertilizer rates, ranging from 17.4 to $29.1 \%$ throughout the year. Forage content of $\mathrm{Ca}, \mathrm{P}$ and lignin was not affected by fertilizer rate or season of the year.
\end{abstract}

\section{INTRODUCTION}

Stargrass (Cynodon nlemfuensis) ${ }^{4}$ is rapidly becoming the most widely planted pasture grass in Puerto Rico. Caro-Costas, Vicente-Chandler and Abruña (3) found that Stargrass pastures produced about $30 \%$ higher gains in weight than Pangolagrass pastures under conditions typical of the humid mountain region of Puerto Rico. The response of Stargrass harvested by cutting to nitrogen fertilization, cutting intervals and height of cutting has been determined by Caro, Abruña and Figarella (2). Caro, Vicente-Chandler and Abruña (5) found that

${ }^{1}$ Manuscript submitted to Editorial Board May 13, 1975.

${ }^{2}$ This paper covers investigations conducted cooperatively between the Agricultural Research Service, USDA, and the Agricultural Experiment Station, Mayaguiez Campus, University of Puerto Rico, Río Piedras, Puerto Rico.

${ }^{3}$ Associate Agronomist in cooperation between the Agricultural Research Service, USDA, and the Agricultural Experiment Station, and Soil Scientists, Agricultural Research Service, USDA, Rio Piedras, Puerto Rico, respectively.

'Possibly a Puerto Rico cultivar of Cynodon dactylon. 
intensively managed Pangolagrass pastures responded to the application of up to $2,688 \mathrm{~kg} / \mathrm{ha}(2,400 \mathrm{lb} / \mathrm{acre})$ of $15-5-10$ fertilizer yearly. Caro-Costas and Vicente-Chandler $(4,6)$ found that Napiergrass pastures responded strongly in beef production and carrying capacity to applications of 1,980 to $4,480 \mathrm{~kg} / \mathrm{ha}(1,800$ to $4,000 \mathrm{lb} /$ acre $)$ of $15-5-10$ yearly depending on rainfall and on intensity of grazing management. VicenteChandler et al. (8) described methods for establishing and managing grasslands in Puerto Rico.

The present study determined the effect of three levels of fertilization on the productivity of intensively managed Stargrass pastures growing on a steep Ultisol under conditions typical of the humid mountain region of Puerto Rico, in terms of beef production, carrying capacity, and yields and composition of the forage.

\section{MATERIALS AND METHODS}

The experiment was conducted over a period of 2 years near Orocovis, at an elevation of about $600 \mathrm{~m}(2,000 \mathrm{ft})$ with a mean annual temperature of about $24^{\circ} \mathrm{C}\left(75^{\circ} \mathrm{F}\right)$ and a seasonal variation of less than $4^{\circ} \mathrm{C}\left(10^{\circ} \mathrm{F}\right)$. The soil is Humatas clay (Ultisol) with an average slope of $30 \%$. A complete randomized block design was used with treatments replicated four times. Twelve individual pastures, each 1 acre in size, were used in the experiment and were provided with water and salt. The soil was limed to about $\mathrm{pH} 6.0$, and the annual fertilizer rate was split into four equal amounts applied each 3 months.

The pastures were grazed by young Holstein heifers. Initially they weighed about $160 \mathrm{~kg}(350 \mathrm{lb})$ and were replaced yearly. A different group of animals grazed the pastures with each fertilizer level. The heifers were treated periodically for parasites and received no feed other than that obtained from the pastures. Two, two and a half, and three "tester" heifers were kept per acre throughout the year in pastures receiving $1,792,3,136$ and $4,480 \mathrm{~kg} / \mathrm{ha}(1,600,2,800$ and 4,000 lb/acre $)$ of fertilizer yearly, respectively. Additional animals were added as required to consume excess forage, using the "put and take" system. Pastures were grazed in rotation with 7 days of grazing followed by 21 days of rest.

The heifers were weighed each time they were moved from one pasture to another. A record was kept of the grazing days and gains in weight for each animal and each pasture. The total digestible nutrients (TDN) produced by each pasture were calculated from these data following recommendations of the Pasture Research Committee (1). Carrying capacity was also calculated and expressed in terms of $273-\mathrm{kg}$ steers/ha (600-lb steers/acre).

During the second year eight $1 \mathrm{~m}^{2}$ areas in each pasture were cut to 
ground level before each grazing. After each grazing eight similar paired areas were also cut to ground level. In both cases the harvested forage was weighed and dried. From these data the amount of dry forage actually consumed by the grazing cattle was determined by difference. The areas sampled for dry forage consumption were varied from grazing cycle to grazing cycle to minimize errors due to trampling and grazing effects.

Before each grazing, 10 forage samples were taken throughout each pasture by plucking to simulate grazing. These samples, which were considered to be typical of the forage consumed by the grazing cattle, were analyzed for crude protein, $\mathrm{Ca}, \mathrm{P}, \mathrm{Si}$ and lignin. In vitro digestibility of the samples was determined by the Van Soest method (7).

\section{RESULTS AND DISCUSSION}

Table 1 shows that rainfall was high $(220.6 \mathrm{~cm}$ or $86.8 \mathrm{in})$ during the first year and low (149.8 cm or $59 \mathrm{in})$ during the second year.

A comparison of the data in tables 2 and 3 shows that productivity of the Stargrass pastures was similar during both a wet and a dry year indicating that this grass is relatively drought resistant. Field observations have shown that it is much more deeply rooted than Pangolagrass.

Stargrass responded to fertilization up to $4,480 \mathrm{~kg} / \mathrm{ha}(4,000 \mathrm{lb} / \mathrm{acre})$ of 15 5-10 yearly during both years (tables 2 and 3 ). On the average the Stargrass pastures produced average annual weight gains of $981,1,337$, and $1,537 \mathrm{~kg} / \mathrm{ha}(876,1,194$ and $1,372 \mathrm{lb} /$ acre) when fertilized with 1,792 , 3,136 and $4,480 \mathrm{~kg} / \mathrm{ha}(1,600,2,800$ and 4,000 lb/acre) of 15-5-10 yearly, respectively. Although these increases are all statistically significant, only the increase of $334 \mathrm{~kg} / \mathrm{ha}$ ( $298 \mathrm{lb} /$ acre) of gain in weight resulting from increasing fertilization from 1,792 to $3,136 \mathrm{~kg} / \mathrm{ha}(1,600$ to 2,800

TABLE 1.-Monthly rainfall at Orocovis during the 2 years of experimentation

\begin{tabular}{lrrrr}
\hline \multicolumn{1}{c}{ Month } & \multicolumn{2}{c}{ First year } & \multicolumn{2}{c}{ Second year } \\
\hline & $C m$ & $I n$ & $\mathrm{Cm}$ & \multicolumn{1}{c}{ In } \\
November & 42.7 & 16.8 & 1.4 & 4.5 \\
December & 40.4 & 15.9 & 14.7 & 5.8 \\
January & 21.1 & 8.3 & 10.7 & 4.2 \\
February & 19.3 & 7.6 & 4.1 & 1.6 \\
March & 5.1 & 2.0 & 31.0 & 12.2 \\
April & 18.8 & 7.4 & 4.3 & 1.7 \\
May & 12.2 & 4.8 & 3.3 & 1.3 \\
June & 4.1 & 1.6 & 4.8 & 1.9 \\
July & 13.2 & 5.2 & 7.6 & 3.0 \\
August & 11.7 & 4.6 & 8.1 & 3.2 \\
September & 8.9 & 3.5 & 26.9 & 10.6 \\
October & 23.1 & 9.1 & 22.9 & 9.0 \\
\hline Total & 220.6 & 86.8 & 149.8 & 59.0 \\
\hline
\end{tabular}


TABLE 2,-Effect of three levels of fertilization on gains in weight made by young Holstein heifers grazing steep Stargrass pastures at Orocovis during the first year of experimentation

\begin{tabular}{rcrrrrrrrr}
\hline $\begin{array}{c}\text { Fertilizer } \\
\text { applied yearly }\end{array}$ & \multicolumn{2}{c}{$\begin{array}{c}\text { Gains in } \\
\text { weight yearly }\end{array}$} & \multicolumn{2}{c}{$\begin{array}{c}\text { Total digestible } \\
\text { nutrients yearly }\end{array}$} & $\begin{array}{c}\text { Carrying capacity } \\
\text { 277-kg (600-lb) } \\
\text { steers }^{2}\end{array}$ & \multicolumn{2}{c}{$\begin{array}{c}\text { Average daily } \\
\text { gains per head }\end{array}$} \\
\hline$K g / h a$ & Lb/acre & Kg/ha & Lb/acre & Kg/ha & Lb/acre & Per ha & Per acre & Kg & Lb \\
1,792 & 1,600 & 1,031 & 921 & 6,905 & 6,165 & 4.98 & 1.99 & .65 & 1.42 \\
3,136 & 2,800 & 1,382 & 1,234 & 9,212 & 8,225 & 6.63 & 2.65 & .63 & 1.38 \\
4,480 & 4,000 & 1,603 & 1,431 & 11,324 & 10,111 & 8.15 & 3.26 & .61 & 1.34 \\
& LSD $^{05}$ & 167 & 149 & 971 & 867 & .78 & .31 & N.S. & N.S. \\
\hline
\end{tabular}

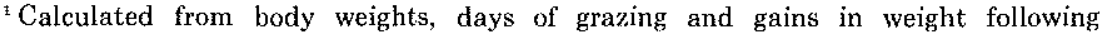
recommendations of the Pasture Research Committee (1).

${ }^{2}$ One $273-\mathrm{kg}(600-\mathrm{lb})$ steer requires $3.86 \mathrm{~kg}(8.5 \mathrm{lb})$ of T.D.N. daily.

${ }^{3}$ For testers cattle which remained on the pastures throughout the year.

TABLE 3.-Effect of three levels of fertilization on productivity of intensively managed Stargrass pastures over the second year of experimentation at Orocovis

\begin{tabular}{|c|c|c|c|c|c|c|c|c|c|c|c|c|}
\hline \multicolumn{2}{|c|}{$\begin{array}{c}\text { Fertilizer } \\
\text { applied yearly }\end{array}$} & \multicolumn{2}{|c|}{$\begin{array}{c}\text { Gain in } \\
\text { weight yearly }\end{array}$} & \multicolumn{2}{|c|}{$\begin{array}{l}\text { Average } \\
\text { daily gains } \\
\text { per head" }\end{array}$} & \multicolumn{2}{|c|}{$\begin{array}{l}\text { Carrying } \\
\text { capacity } \\
273-\mathrm{kg} \\
(600-1 \mathrm{~b}) \\
\text { steers }^{2}\end{array}$} & \multicolumn{2}{|c|}{$\begin{array}{l}\text { Total digest- } \\
\text { ible nutrients } \\
\text { yearly }\end{array}$} & \multicolumn{2}{|c|}{$\begin{array}{l}\text { Forage con- } \\
\text { sumed by } \\
\text { grazing cattle } \\
\text { yearly }\end{array}$} & \multirow{2}{*}{$\begin{array}{c}\begin{array}{c}\text { Apparent } \\
\text { digesti- } \\
\text { bility of } \\
\text { consumed } \\
\text { forage }\end{array} \\
\%\end{array}$} \\
\hline$K g / h a$ & $\begin{array}{l}\text { Lb/ } \\
\text { acre }\end{array}$ & $K g / h a$ & $\begin{array}{c}L b / \\
\text { acre }\end{array}$ & $K g$ & $L b$ & $\begin{array}{l}\text { Per } \\
\text { ha }\end{array}$ & $\begin{array}{l}\text { Per } \\
\text { acre }\end{array}$ & $K g / h a$ & $\begin{array}{c}L b / \\
\text { acre }\end{array}$ & $\mathrm{Kg} / \mathrm{ha}$ & $\begin{array}{c}\mathrm{Lb} / \\
\text { acre }\end{array}$ & \\
\hline 1,792 & 1,600 & 977 & 872 & .61 & 1.35 & 5.33 & 2.13 & 7,395 & 6,603 & 13,059 & 11,660 & 56.6 \\
\hline 3,136 & 2,800 & 1,292 & 1,154 & .64 & 1.40 & 6.98 & 2.79 & 9,688 & 8,650 & 13,720 & 12,250 & 65.3 \\
\hline \multirow[t]{2}{*}{4,480} & 4,000 & 1,472 & 1,314 & .61 & 1.35 & 7.73 & 3.09 & 10,738 & 9,588 & 18,095 & 16,156 & 59.4 \\
\hline & $\operatorname{LSD}^{05}$ & 128 & 114 & N.S. & N.S. & .40 & .16 & 569 & 508 & 5,025 & 4,487 & N.S. \\
\hline
\end{tabular}

${ }^{1}$ For testers cattle which remained on the pastures throughout the year.

${ }^{2}$ One $273-\mathrm{kg}(600-\mathrm{lb})$ steer requires $3.86 \mathrm{~kg}(8.5 \mathrm{lb})$ T.D.N. daily.

${ }^{3}$ Calculated from body weight, days of grazing and gains in weight following recommendations of the Pasture Research Committee (1).

'Forage consumed T.D.N.

lb/acre) yearly would be economical at present prices of beef and fertilizers.

Carrying capacity of the pastures also increased with fertilization during both years. On the average the pastures had a carrying capacity of $5.15,6.80$ and $7.93273-\mathrm{kg}$ steers/ha $(2.06,2.72$ and $3.17600-1 \mathrm{~b}$ steers/ acre) with $1,792,3,136$, and $4,480 \mathrm{~kg} / \mathrm{ha}(1,600,2,800$ and $4,000 \mathrm{lb} /$ acre $)$ of fertilizer yearly, respectively.

Average daily gain per head was not affected by fertilization, averaging about $.61 \mathrm{~kg}(1.35 \mathrm{lb})$ daily (tables 2,3$)$.

Amount of forage consumed by the grazing cattle also increased with increased fertilization from $13,059 \mathrm{~kg} / \mathrm{ha}(11,660 \mathrm{lb} / \mathrm{acre})$ yearly with 
TABLE 4.-Percent composition of Stargrass samples obtained by plucking to simulate grazing, as affected by level of fertilization and season of the year

\begin{tabular}{|c|c|c|c|c|c|c|c|c|c|c|c|c|c|c|c|c|c|c|}
\hline \multirow[t]{2}{*}{ Month } & \multicolumn{3}{|c|}{$\begin{array}{l}\text { Apparent digesti- } \\
\text { bility of dry matter }\end{array}$} & \multicolumn{3}{|c|}{ Lignin } & \multicolumn{3}{|c|}{ Silica } & \multicolumn{3}{|c|}{ Crude protein } & \multicolumn{3}{|c|}{ Phosphorus } & \multicolumn{3}{|c|}{ Calcium } \\
\hline & $A^{2}$ & $B$ & $C$ & A & $B$ & $C$ & $A$ & $B$ & $C$ & $A$ & $B$ & C & $A$ & $B$ & $C$ & $A$ & $B$ & $C$ \\
\hline Dec. $/ 71$ & 56 & 67 & 70 & 5.3 & 5.0 & 4.1 & 2.9 & 2.0 & 2.1 & 22.8 & 19.6 & 24.2 & 0.24 & 0.25 & 0.30 & 0.49 & 0.47 & 0.45 \\
\hline Jan./72 & 82 & 72 & 70 & 5.4 & 3.9 & 4.7 & 2.9 & 1.4 & 1.9 & 27.5 & 26.3 & 24.7 & 0.26 & 0.26 & 0.29 & 0.48 & 0.44 & 0.48 \\
\hline Feb. $/ 72$ & 70 & 69 & 70 & 4.9 & 4.5 & 4.0 & 1.9 & 1.6 & 1.1 & 22.2 & 23.3 & 24.7 & 0.21 & 0.22 & 0.24 & 0.45 & 0.41 & 0.40 \\
\hline Mar./72 & 65 & 58 & 68 & 4.9 & 5.8 & 4.1 & 3.4 & 2.6 & 2.4 & 19.7 & 17.4 & 22.2 & 0.20 & 0.17 & 0.19 & 0.53 & 0.35 & 0.41 \\
\hline Apr. $/ 72$ & 72 & 69 & 71 & 4.7 & 4.0 & 4.2 & 1.5 & 1.5 & 1.8 & 23.1 & 24.1 & 24.3 & 0.29 & 0.22 & 0.21 & 0.49 & 0.40 & 0.44 \\
\hline May/72 & 70 & 68 & 69 & 4.8 & 4.2 & 3.7 & 2.5 & 1.6 & 2.3 & 21.9 & 22.7 & 22.5 & 0.22 & 0.25 & 0.20 & 0.43 & 0.38 & 0.37 \\
\hline June/72 & 68 & 66 & 68 & 5.6 & 4.0 & 4.1 & 2.5 & 1.3 & 2.1 & 17.7 & 18.9 & 21.4 & 0.20 & 0.26 & 0.19 & 0.40 & 0.39 & 0.37 \\
\hline July/72 & 69 & 70 & 71 & 4.5 & 3.9 & 4.2 & 2.4 & 1.1 & 2.4 & 22.1 & 23.3 & 25.6 & 0.26 & 0.26 & 0.24 & 0.41 & 0.38 & 0.36 \\
\hline Aug./72 & 72 & 72 & 73 & 4.3 & 3.9 & 3.7 & 2.4 & .9 & 1.5 & 23.8 & 25.9 & 29.1 & 0.24 & 0.21 & 0.25 & 0.48 & 0.42 & 0.31 \\
\hline Sept./72 & 69 & 72 & 71 & 4.1 & 3.5 & 3.4 & 2.2 & 1.1 & 1.4 & 18.4 & 22.1 & 23.8 & 0.22 & 0.17 & 0.19 & 0.38 & 0.35 & 0.31 \\
\hline Oct. $/ 72$ & 70 & 70 & 72 & 4.1 & 4.0 & 3.3 & 2.0 & 1.6 & .7 & 22.8 & 24.3 & 24.8 & 0.18 & 0.17 & 0.18 & 0.40 & 0.31 & 0.31 \\
\hline Average & 69.4 & 68.5 & 70.3 & 4.8 & 4.2 & 4.0 & 2.4 & 1.5 & 1.8 & 22.0 & 22.5 & 24.3 & 0.23 & 0.22 & 0.23 & 0.41 & 0.39 & 0.38 \\
\hline
\end{tabular}

${ }^{1}$ Determined by the "in vitro" method of Van Soest et al. (7).

${ }^{2} \mathrm{~A}-1,792 \mathrm{~kg} / \mathrm{ha}(1,600 \mathrm{lb} / \mathrm{acre})$ of $15-5-10$ yearly. B-3,136 kg/ha $(2,800 \mathrm{lb} / \mathrm{acre})$ of $15-5-10$ yearly. $\mathrm{C}-4,480 \mathrm{~kg} / \mathrm{ha}(4,000 \mathrm{lb} / \mathrm{acre})$ of $15-5-10$ yearly. 
$1,792 \mathrm{~kg} / \mathrm{ha}(1,600 \mathrm{lb} / \mathrm{acre})$ of fertilizer to $18,095 \mathrm{~kg} / \mathrm{ha}(16,156 \mathrm{lb} /$ acre $)$ yearly with $4,480 \mathrm{~kg} / \mathrm{ha}(4,000 \mathrm{lb} /$ acre) of fertilizer (table 3 ).

Apparent digestibility of the forage consumed, calculated from the total digestible nutrients utilized by the cattle and the dry forage consumed, was not affected by fertilization and ranged from 59.4 to $65.3 \%$ (table 3 ).

In vitro digestibility of the forage was not affected by fertilization nor did it vary consistently with season of the year, averaging about $70 \%$ for the year (table 4 ).

Lignin content of the forage did not vary much with season of the year but tended to decrease with increasing fertilization (table 4).

Silica content of the forage varied widely throughout the year ranging from .9 to $3.4 \%$ but was not consistently affected by fertilizer rate.

Crude protein content of the forage consumed by the grazing cattle was very high at all fertilizer rates and seasons of the year, generally approximating that of alfalfa. Crude protein content varied from 17.4 to $29.1 \%$ during the year (table 4 ) with averages for the year increasing from 22.0 to $24.3 \%$ with increasing fertilization. There was no consistent effect of rainfall or season of the year on protein content of the forage.

Forage content of $\mathrm{P}$ and $\mathrm{Ca}$ was not affected by fertilizer rates and varied considerably throughout averaging .23 and .40\% for the year, respectively.

\section{RESUMEN}

Pastos de yerba Estrella en la región húmeda montañosa de Puerto Rico respondieron favorablemente en términos de gananicia de peso y capacidad de pastoreo según se aumentaron los niveles de abonamiento de 1,792 a 3,136 a $4,480 \mathrm{Kg} . / \mathrm{Ha} .(1,600,2,800$ y 4,000 libras/acre) de abono 15-5-10 al año. Con la aplicación de 3,136 Kg./ $\mathrm{Ha}$ (2,800 libras por acre) al año los pastos de yerba Estrella produjeron 1,337 Kg./Ha. (1,194 libras por acre) de aumento de peso al año y alcanzaron una capacidad de pastoreo equivalente a 6.8 novillos de $273 \mathrm{Kg} . / \mathrm{Ha}$. (2.72 novillos de 600 libras por acre). El aumento de peso medio por día y cabeza fue de $.61 \mathrm{~kg}$. (1.35 libras). Este no fue afectado por el abonamiento.

La digestibilidad aparente del forraje, ya fuera determinada in vitro o calculada a base de los nutrimentos digeribles utilizados por el ganado y el forraje que éste consumió, tampoco fue afectada por el abonamiento.

El contenido de proteína del forraje ingerido por el ganado fue muy alto en todos los niveles de abonamiento, variando de 17.4 a 29.1 por 100 a través del año. El contenido en calcio, fósforo y lignina del forraje no fue afectado por el abonamiento ni por la época del aก̃o.

\section{LITERATURE CITED}

1. Anonymous, Report on pasture investigations techniques, Joint Comm. of Amer. Dairy Sci. Assoc., Amer. Soc. Agron., and Amer. Soc. An. Prod, J. Dairy Sci. 26: 353-69, 1943.

2. Caro-Costas, R., Abruña, F., and Figarella, J., Effect of nitrogen rates, harvest interval 
and cutting heights on yield and composition of Star grass in Puerto Rico, J. Agr. Univ. P.R. 56 (3): 267-79, 1972.

3. - - - - and Vicente-Chandler, J., Comparison of heavily fertilized Pangola and Star grass pastures in terms of beef production and carrying capacity in the humid mountain region of Puerto Rico, J. Agr. Univ. P.R. 56 (2): 104-9, 1972.

4. - - and Vicente-Chandler, J., Effect of fertilization on carrying capacity and beef production by Napier grass pasture, Agron. J. 53 (3): 204-5, 1961.

5. - - - — a a a Abruña, F., The effect of four levels of fertilization on beef production and carrying capacity of Pangola grass pastures in the humid mountain region of Puerto Rico, J. Agr. Univ. P.R. 56 (3): 219-22, 1972.

6. - - and - Effect of heavy rates of fertilization on beef production and carrying capacity of Napier grass pastures over 5 consecutive years of grazing, J. Agr. Univ. P.R. 56 (3): 223-7, 1972.

7. Van Soest, R. J., Win, R. H., and Moore, L. A., Estimation of the true digestibility of forages by the in vitro digestion on cell walls, Proc. P.R.S. $10^{\text {th }}$ Inter. Grassland Conf. Helsinki, Finland 438, 1960.

8. Vicente-Chandler, J., Abruña, F., Caro-Costas, R., Figarella, J., Pearson, R. W., and Silva, S., Intensive grassland management in the humid tropics of Puerto Rico, Agr. Exp. Sta. Univ. P.R., Bull. 233, Feb. 1974. 